\title{
A Mathematical Modelling of Crimes Against Women in Rajasthan
}

\author{
Ann Mary Thomas, Bhavya Kumawat, Anjali Mewada, Jitendra Shreemali, Prasun Chakrabarti
}

\begin{abstract}
Crimes against women represent one of the evils of societies more so in societies where women are more vulnerable. Based on the prevailing classification of crimes against women, the study aims at examining whether different crimes behave identically or differently. The mathematical model shows that while crimes like rape and cruelty by husband follow an exponential function, crimes like kidnapping and abduction, assault with the intent to insult their modesty and indecent representation of women follow a (quadratic) polynomial function. Finally, immoral trafficking of women appears to follow none of the functions/distributions considered. Different approaches to addressing these crimes may, therefore, work better than a single approach.
\end{abstract}

Key words: Rape, Dowry Death, Assault on Women with Intent to Insult her Modesty, Cruelty by Husband or Relatives, Immoral traffic on Women, Indecent Representation of Women.

\section{INTRODUCTION}

The brutal gang rape of a 23-year-old, later named as NIRBHAYA, occurred in Munirka, Delhi, shook our country to the core. It was then when it came to notice that we all live in a society where violence against women is mainstream. It has become a common practice in the current male dominant society to overpower the opposite sex. Nobody raises an issue if they see something wrong unless and until it happens to them or to their own family. It has been from Nirbhaya to Dr. Priyanka Reddy, how much have we really improved? As of 2017 NCRB report, Uttar Pradesh ranked first with 56,011 cases of crime against women. [1]

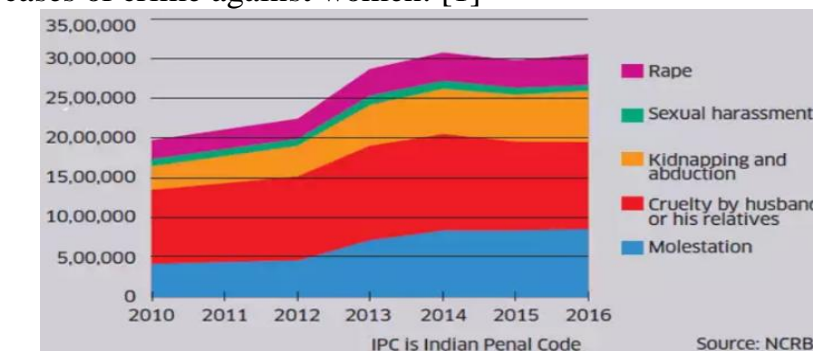

Source:

https://economictimes.indiatimes.com/news/politics-and-nation/what-crime-sta ts-dont-say/articleshow/66787792.cms?from $=\mathrm{mdr}$

Revised Manuscript Received on March 5, 2020.

Ann Mary Thomas, Techno India NJR Institute of Technology Udaipur 313003

annmarythomas309@gmail.com

Bhavya Kumawat, Techno India NJR Institute of Technology Udaipur 313003

Anjali Mewada, Techno India NJR Institute of Technology Udaipur 313003

Jitendra Shreemali, Techno India NJR Institute of Technology Udaipur 313003

Prasun Chakrabarti, Techno India NJR Institute of Technology Udaipur 313003
According to our constitution every crime must be reported and any woman who faces violence of any form should get justice. The data we have about the reported crimes is just the tip of the iceberg. Many cases go unreported due to fear of shaming.

The rape culture is the termite of the society that is eating us from the inside. As a society we, sometimes, appear to have an attitude of trivializing sexual assault and blaming the victim driven by a flawed image of the victim and her actions preceding the crime. People engage in honor killing in order to save their family's reputation.

Not only rape but other crimes against women include persecution for dowry, dowry deaths, abduction, sexual assault, insult to modesty, trafficking, honor killing, indecency, cruelty by intimate partner or relatives, etc. In some of the cases it is just not men "the accused", but women also.

Gender bias in the society further results in increase in the crime against women. Many parents still prefer male child over female though the reasons could vary. This contributes to the low sex ratios. The female child is nurtured with the thought of being submissive to the males and the male child is often given freedom and preferences compared to the opposite sex which obviously affects their mindsets. Children imitate their parents. If the family alone does not respect its own women how would you expect the further generations to?

The high illiteracy rate among the Indian women is a major drawback for our country's economy. Many parents spend less on the education of their girl child because of the typical ideology "The girls are to be married and sent off". Even when the girl manages to get the education, she is restrained from working and providing an income to her household. This is a major disadvantage for our country's economy. India's first Prime Minister, Hon'ble Jawahar Lal Nehru said that a nation could well be judged on the basis of condition of women in the nation.

When these conditions exist in our nation, the society has to accept some blame, if not all of it. Our government has provided various laws for the empowerment of women. Some of them are as follows [3]: -

Women specific legislation as distinct from women related legislation: (a) The Immoral Traffic Prevention Act of 1956; (b) The Dowry Prohibition Act of 1961; (c) The Act on Indecent Representation of Women (year 1986); (d) The 1987 Commission of Sati (Prevention) Act; (e) The 2005 Act for Protection of Women from Domestic Violence; (f) The Sexual Harassment of Women at Workplace Act, 2013; and

(g) The Criminal Law

(Amendment) Act, 2013 
Women related legislation, on the other hand, include: (a) The Indian Penal Code of 1860 and (b) The Indian Evidence Act of the year 1872 .

Even though cases are being filed, due to huge backlogs in the court the case proceeds with a snail's pace. Worst is the case, when the accused is released and tries to blackmail or threaten the victim.

An identical incident took place on Dec 5, 2019 wherein the victim of rape (a mere 23-year-old) was set on fire by a group of men that included the alleged rapist while she was going to the court to participate in a court hearing on her own case in the state of Uttar Pradesh, India. [4]

The key is education. Education of the basic rights of each individual, to respect and trust other's and to care for everyone. We need to change the stereotype that women don't support other women.

A woman alone has power; collectively we have impact [5]

\section{LITERATURE REVIEW}

India's Daughter - documentary film directed by Udwin (2017). It is a part of the BBC's Storyville series. [6]

India's Daughter's writer has invested some time talking to rapists in Delhi's Tihar Jail finding the answer to the question,

"What might be the circumstances that produce a monster like these in the society?"

We always thought, what prompts these men?

During the interviews, most men made excuses or gave justifications for their actions. A lot of them do not even realize that what they have committed is rape. There were only few who said we are repenting. Others held out against any accusations and justified their wrongdoings and blamed actions onto the victim.

Rapists had a poor opinion for women in general. They never regretted it or realized how their actions had affected other people and destroyed lives.

What they have committed is because of upbringing and thought process.

Men acquire a distorted and flawed understanding of masculinity, while women learn to be submissive. It often happens in the same family.

To gain an idea of the mindset of Rapists, they were tested on Attitudes Towards Women Scale(1978). [7]

It consists of statements that discuss attitudes towards women in society which different people have.

Assailants were asked to express their feelings about each statement by specifying whether they (A) agree strongly, (B) agree mildly, (C) disagree mildly, or (D) disagree strongly. Source -Attitudes Towards Women Scale (Spence, Helmrich \& Stapp, 1978)

\section{A. An Indian judge thinks rapists should marry their victims.}

An Indian judge suggested that the attacker should be obliged to marry the rape victim. A judge from the Madras High Court letting a rapist out of prison on bail so he could sort the matter with his victim also points to a rather patriarchal attitude in the society.
At birth, a person is identified as male or female based on what their bodies look like. But some people discover themselves different from their initial gender when they were born. These people recognize themselves as transgender (2016).[8]

The girl after gender reassignment surgery married another girl whom she does not even feel compassion for. She is destroying two innocent lives.

Morality is knowing the difference between good and bad. Morality is again the responsibility of parents $\&$ teachers and relatives/friends.

The society needs to be blamed.

Specially in India the attackers have very less fear of police, judiciary system and government. Judiciary is very slow in India.

\section{METHODOLOGY}

The study aims to providing a mathematical model for crimes committed against women in the state of Rajasthan. Data was collected from the site www.data.gov.in. Crimes are categorized as follows:

- Rape

- Kidnapping and abduction of women

- A dowry related death

- An assault on a woman with an intent to outrage her modesty

- Acts of cruelty by husband or relatives

- Immoral trafficking of women

- Indecent representation of women

Based on data from 2001 to 2012, the study examined whether these crimes follow identical mathematical and graphical pattern since a common mathematical pattern would suggest a common approach to solving the problems. The data set originally had data from all states in the country. Data from Rajasthan was separated out and plotted followed by trend line and model being established for all categories of crimes for the period aiming for the highest $\mathrm{R}$-squared value possible. The models considered were linear, polynomial, exponential, logarithmic, power and moving averages. Findings of this analysis is presented below.

\section{FINDINGS AND DISCUSSIONS}

The study brings out a clear difference in the patterns of different crimes. Given below is the graphical representation of the crimes along with the trend line. The mathematical equation representing the trend line along with the corresponding $\mathrm{R}^{2}$ value is ss given below:

\section{Analysis Of Rape Data:}

The trend line shows that rapes grew exponentially during 2001-12 period with the equation being:

No. of rapes $/=849.49 \mathrm{e}^{0.0629 \mathrm{x}}$; $(\mathrm{x}$ represents the year)

The corresponding $\mathrm{R}^{2}$ is 0.8493 


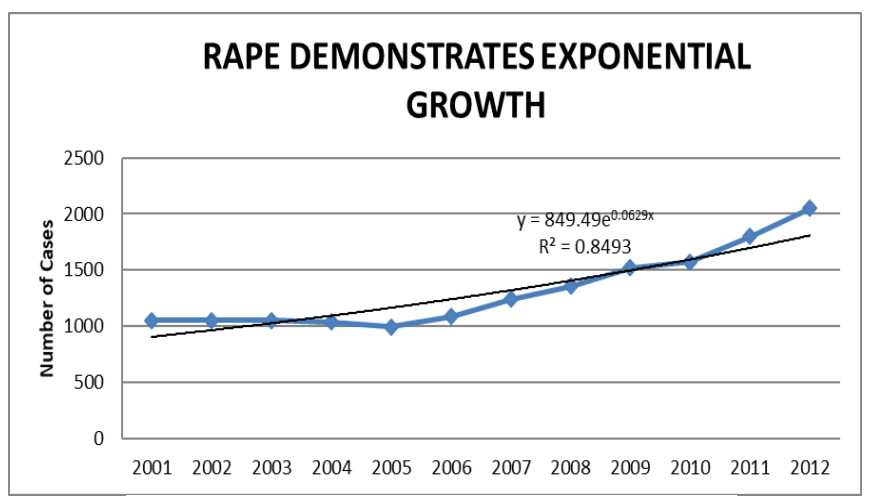

Fig(1) demonstrating exponential growth

\section{Analysis Of Kidnapping \&Abduction Data:}

The trend line shows that kidnapping \&abduction shows polynomial growth function during 2001-12 period with the equation being:

No. of kidnapping \& abduction/ $=26.498 \mathrm{x}^{2}-273.09 \mathrm{x}+$ 2395.72 where (x represents year)

The corresponding $\mathrm{R}^{2}$ is 0.8766

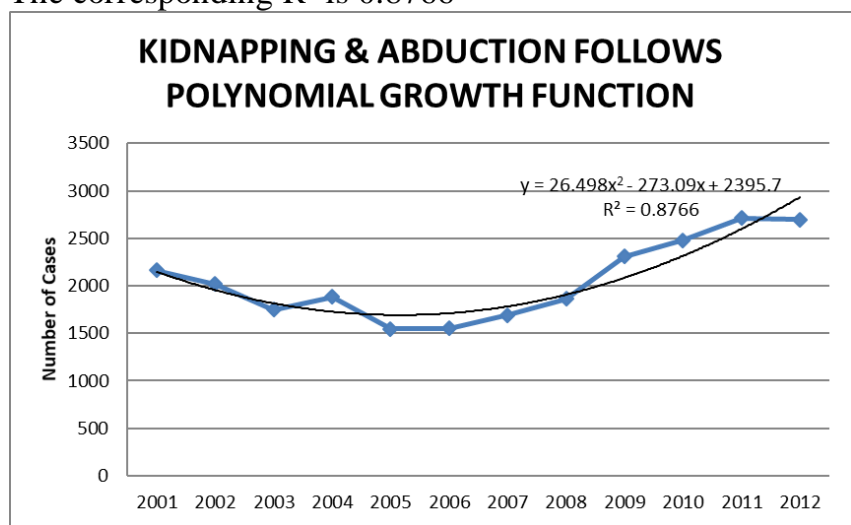

Fig(2) representing polynomial growth function by kidnapping and abduction

\section{Analysis of CASES ON DOWRY DEATHS:}

The trend line shows that dowry death shows polynomial growth function during 2001-12 period with the equation being:

No. of dowry deaths $/=1.1079 \mathrm{x}^{2}-3.1019 \mathrm{x}+382.32$

wherein $\mathrm{x}$ represents year)

The corresponding $\mathrm{R}^{2}$ is 0.827

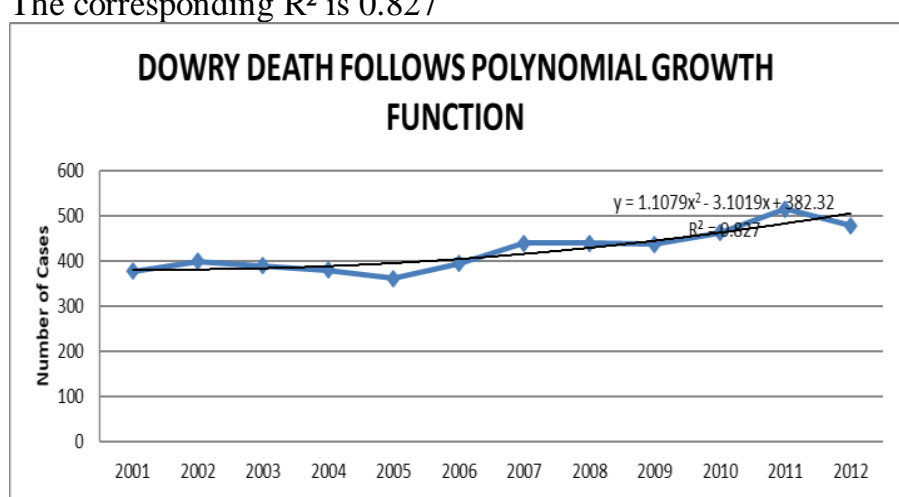

Fig(3) represents polynomial growth function by dowry deaths

Analysis Of Data On Assault On Women:
The trend line shows that dowry death shows polynomial growth function during 2001-12 period with the equation being:

No. of assaults on women $/$ year $=2.2795 x^{2}-74.105 x+2929.3$ wherein $\mathrm{x}$ represents year)

The corresponding $\mathrm{R}^{2}$ is 0.8386

\section{ASSAULT ON WOMEN WITH INTENT TO OUTRAGE HER} MODESTY FOLLOWS POLYNOMIAL GROWTH FUNCTION

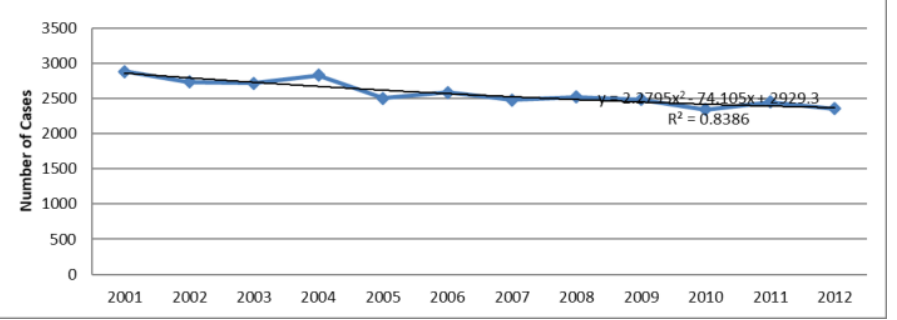

Fig(4) represents polynomial growth function by assault on women with intent to outrage her

\section{Data On Cruelty By Husband Or Relatives:}

The trend line shows that cruelty by husband or relatives shows exponential growth during 2001-12 period with the equation being:

Cases of Cruelty..../year $=4572.9 \mathrm{e}^{0.0852 \mathrm{x}}$

(wherein $\mathrm{x}$ represents year)

The corresponding $\mathrm{R}^{2}=0.9386$

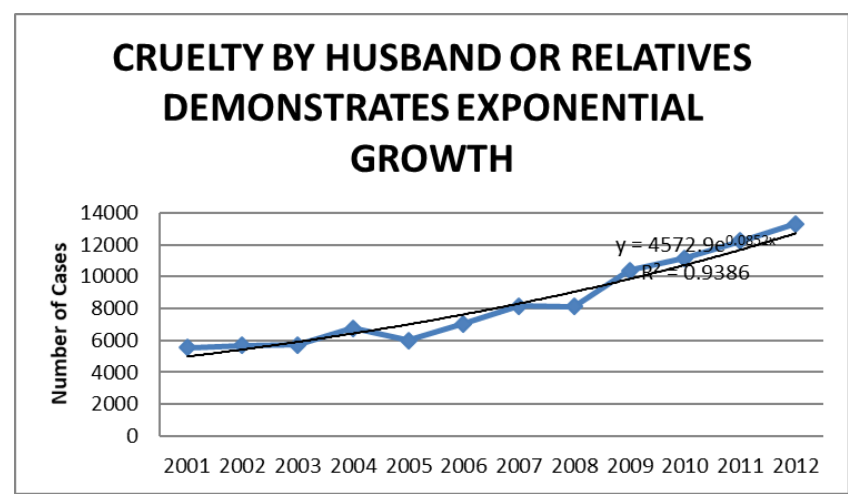

Fig(5) represents exponential growth by cruelty by husband or relatives

Immoral Trafficking Of Women:

The trend line shows that immoral trafficking of women behaves differently during 2001-12 period. It does not follow any of the distributions considered suggesting that the underlying factors causing this crime may be entirely different. 


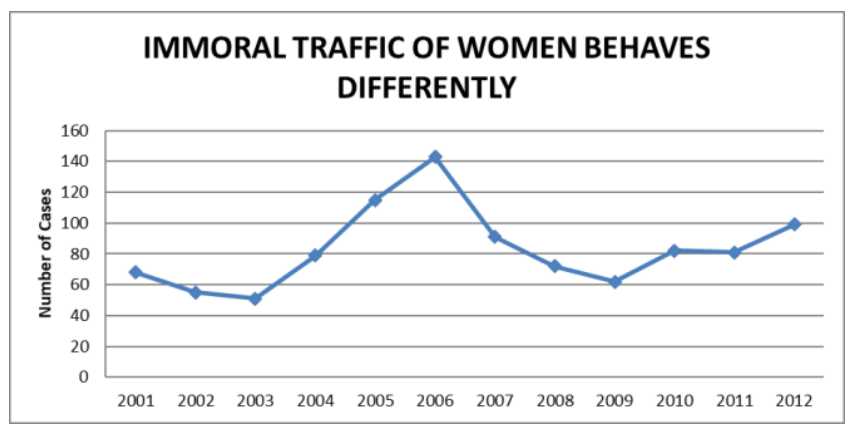

Fig(6) represents graph behaving differently for immoral trafficking of women

\section{Indecent Representatiion Of Women:}

The trend line shows that indecent representation of women shows polynomial growth function during 2001-12 period with the equation being:

Cases of Indecent.../year $=-1.9298 x^{2}+27.42 x+15.886$; wherein $\mathrm{x}$ represents the year

The corresponding $\mathrm{R}^{2}$ is 0.8213

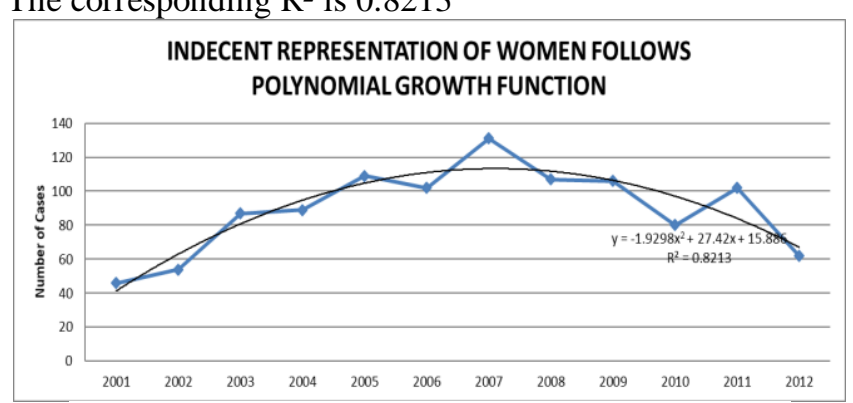

Fig(7) represents polynomial growth function by indecent representation of women

\section{REFERENCES}

1. Gowthaman, N. (2019). NCRB Crime in India 2017 report reveals most unsafe places for women. Retrieved from: -https://yourstory.com/herstory/2019/10/most-unsafe-places-women-indi a-ncrb-report

2. Shrinivasan,R(2018).What crime stats don't say. Retrieved from:https://economictimes.indiatimes.com/news/politics-and-nation/wh at-crime-stats-dont-say/articleshow/66787792.cms?from $=\mathrm{mdr}$

3. 3. Pujara D, Bhatia G, Singh K and Gopalakrishnan R (2019): Compiled by authors. Statistics on rape in India and some well-known cases. Retrieved from: https://www.reuters.com/article/us-india-rape-factbox/statistics-on-rapein-india-and-some-well-known-cases-idUSKBN1YA0UV

4. G.O.Young. REUTERS.Statistics on rape in India and some well-known casesRetrieved

http://ncw.nic.in/important-links/List-of-Laws-Related-to-Women

5. Zallis,S(2019) Power Of The Pack: Women Who

6. Support Women Are More Successful

7. Retrieved from:

8. https://www.forbes.com/sites/shelleyzalis/2019/03/06/power-of-the-pack -women-who-support-women-are-more-successful/\#142659af1771

9. The Washington Post.Doshi v(2017). A woman interviewed 100 convicted rapists in India. This is what she learned.Retrieved from:

10. https://www.washingtonpost.com/news/worldviews/wp/2017/09/11/a-w oman-interviewed-100-convicted-rapists-in-india-this-is-what-she-learne d/

11. Spence, Helmrich \& Stapp (1978). Attitudes Towards Women Scale. Retrieved from: http://www.yorku.ca/rokada/psyctest/attwom2.pdf

12. G. O. Young. (2016) national center for transgender equality. Frequently Asked Questions about Transgender People Retrieved from:

13. https://transequality.org/issues/resources/frequently-asked-questions-abo ut-transgender-people

\section{AUTHORS PROFILE}

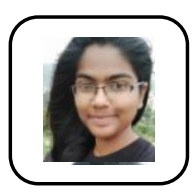

Ann Mary Thomas

Second Year Student Pursuing B. Tech in Computer Science Department of Techno India NJR Institute of Technology. Area of Interest is Deep Learning, Artificial Intelligence and Data Science. Email-

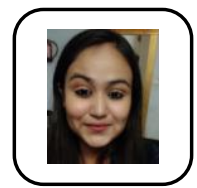

\section{Bhavya Kumawat}

Second Year Student Pursuing B. Tech in Computer Science Department of Techno India NJR Institute of Technology. Area of Interest is cloud computing, Machine Learning and Artificial Intelligence.

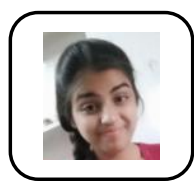

\section{Anjali Mewada}

Second Year Student Pursuing B. Tech in Computer Science Department of Techno India NJR Institute of Technology. Area of Interest is Machine Learning,

Prof Jitendra Shreemali is a graduate from IIT

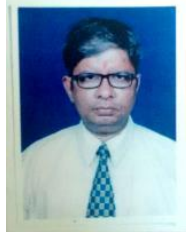
Madras with post graduate from IIM Bangalore. He is working as Professor at Techno India NJR Institute of Technology Udaipur.

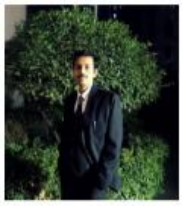

Prasun Chakrabarti received his $\mathrm{PhD}$ (Engg) from Jadavpur University in 2009. He is working as Executive Dean , Techno India NJR Institute of Technology 